\title{
Regional supply-demand discrepancies: a training perspective
}

Citation for published version (APA):

Diephuis, B. J., Nekkers, G. J. A., de Grip, A., \& van Eijs, P. W. L. J. (2000). Regional supply-demand discrepancies: a training perspective. Researchcentrum voor Onderwijs en Arbeidsmarkt, Faculteit der Economische Wetenschappen. ROA Working Papers No. 5E https://doi.org/10.26481/umarow.200005E

Document status and date:

Published: 01/01/2000

DOI:

10.26481/umarow.200005E

Document Version:

Publisher's PDF, also known as Version of record

\section{Please check the document version of this publication:}

- A submitted manuscript is the version of the article upon submission and before peer-review. There can be important differences between the submitted version and the official published version of record.

People interested in the research are advised to contact the author for the final version of the publication, or visit the DOI to the publisher's website.

- The final author version and the galley proof are versions of the publication after peer review.

- The final published version features the final layout of the paper including the volume, issue and page numbers.

Link to publication

\footnotetext{
General rights rights.

- You may freely distribute the URL identifying the publication in the public portal. please follow below link for the End User Agreement:

www.umlib.nl/taverne-license

Take down policy

If you believe that this document breaches copyright please contact us at:

repository@maastrichtuniversity.nl

providing details and we will investigate your claim.
}

Copyright and moral rights for the publications made accessible in the public portal are retained by the authors and/or other copyright owners and it is a condition of accessing publications that users recognise and abide by the legal requirements associated with these

- Users may download and print one copy of any publication from the public portal for the purpose of private study or research.

- You may not further distribute the material or use it for any profit-making activity or commercial gain

If the publication is distributed under the terms of Article $25 \mathrm{fa}$ of the Dutch Copyright Act, indicated by the "Taverne" license above, 


\section{Regional Supply-Demand Discrepancies: A Training Perspective}

ROA-W-2000/5E

Geralt Nekkers, Patrick van Eijs, Andries de Grip, Bart Diephuis

Research Centre for Education and the Labour Market

Faculty of Economics and Business Administration

Maastricht University

Maastricht, October 2000 
ISBN 90-5321-293-0

Sec00176/GN 


\section{Contents}

Pages

Abstract

1 Introduction 1

2 Matching problems and training 2

3 The data: sources and methods $\quad 7$

4 Matching problems and training perspectives: A brief illustration 9

5 Conclusions 11

References 11

Appendix: Labour market indicators for different types of education 13 



\begin{abstract}
In this paper we develop a framework that is based on short-term projections of matching problems. This framework enables us to investigate the potential for reducing matching problems on the regional labour market by means of training policies that focus on the unemployed. For this purpose we distinguish between quantitative and qualitative supply shortages. The analysis is conducted at a disaggregated level, i.e. with respect to the various educational types. The results of our empirical analysis show that both additional training and retraining programmes for unemployed workers may improve their labour market opportunities, while at the same time reducing labour market imbalances.
\end{abstract}




\section{Introduction}

Socio-economic, organisational and technological developments have significant effects on labour market outcomes. As skill requirements increase, the need for a well-educated and highly flexible working population gains importance. ${ }^{1}$ Since education is not instantaneous, usually the necessary adjustments to labour supply ("necessary" from a planning perspective) lag behind changes in labour demand. This process is bound to put pressure on the match between labour supply and demand and may induce discrepancies within various labour market segments. One way of attacking discrepancies is the use of active labour market policies. Taking into account the time-to-educate argument, such policies will be most effective when they are able to anticipate on expected future discrepancies. ${ }^{2}$ This calls for an explicit forecasting approach.

Since labour markets are inherently spatial in nature, demand and supply frequently display important region-specific characteristics. This means that if matching problems were to occur, regional labour market policies are likely to be most efficient (cf. Van Dijk and De Grip, 1998). Specifically, tackling problems at the regional level has a clear advantage: Social partners and public employment services mostly have a regional organisational structure which enables them to closely observe the quality of the regional demand-supply match. If necessary, they can improve upon this match in cooperation with regional and local governments and schools. This view is supported by policies of the Public Employment Services in the Netherlands for example. Van der Laan (1996) observes that in various European countries there is a tendency towards solving labour market problems particularly at a regional level.

Obviously, what policy should be used depends crucially on the type of problem one is confronted with. Thus, a situation of deficient demand may to some extent be solved by increasing aggregate demand. Alternatively, if recruitment problems in specific labour market segments are caused by a deficiency of suited supply, additional training and retraining of unemployed workers are among the most important policy instruments ${ }^{3}$ (ROA, 1999). In this paper we focus on the latter by considering whether or not the use of labour market

1. Van der Laan and Ruesga (1998) discuss more extensively how countries in Western Europe switched from a regulation model to, as they call it, a "flexible specialisation" model, which facilitates the necessary adjustments to quickly changing global circumstances (cf. e.g. ILO, 1995).

2. If educational choices or policies would be based on current labour market mismatches, future workers might be faced with a changed labour market situation at the moment they finish their education. As e.g. Freeman (1975) and Zarkin (1983) show, basing one's decisions on current shortages may cause overshooting and turn the initial shortage into a situation of excess supply.

3. Some authors question the effectiveness of training programmes: Van Paridon (2000) notes that the persons to be trained in a specific labour market segment may simply not be available. This is one thing we shall be looking at in this paper. Others hint at the importance of other factors (such as motivational aspects) in determining whether or not unemployed workers will be successful in finding a job (e.g. CPB, 2000). 
indicators may help trace the additional training and retraining possibilities of unemployed workers, where we shall be taking a forecasting perspective. It is to be noted that in this paper we only focus on training programmes aimed at reducing matching problems on the labour market ${ }^{4}$, where training should be interpreted broadly.

The structure of this paper is as follows: Section 2 deals with the conceptual framework and the labour market indicators which can be derived from this framework. In sections 3 and 4 we describe the data and apply our framework to the labour market in the Dutch province of Limburg. ${ }^{5}$ Section 5 concludes.

\section{Matching problems and training}

\section{Matching problems}

Matching problems between demand and supply can occur in various ways. A distinction can be made between quantitative and qualitative matching problems. Van Hoof and Dronkers (1980) describe:

- quantitative matching problems as the imbalance between the amount of workers having specific skills who are available on the labour market and the number of jobs available for which these workers have the adequate skills and

- qualitative matching problems as the discrepancy between the level and type of skills acquired by those offering their labour services and the requirements imposed on workers in jobs for which they have the adequate skills.

These discrepancies can be related to the way in which training programmes are best used (De Grip, 1987). We distinguish between additional training programmes, which are meant for increasing workers' skills in their own field of work, and retraining programmes that retrain workers in an other field of work. This means that additional training programmes can be an effective instrument to reduce qualitative discrepancies, whereas retraining programmes are more effective if the discrepancies have a quantitative character.

\section{Characterising matching problems}

Three basic notions underlie the framework used to determine the character of labour supply and demand mismatches in a particular labour market segment and its implications for training policies. In the first place, as already noted, since training programmes take time, training policies will be most effective if they are able to anticipate on expected future labour

4. Training programmes merely aimed at improving the relative position and labour market perspectives of those having a very weak position on the labour market are not discussed here (cf. Schmid et al., 1996).

5. In this paper the emphasis is on low and intermediate types of education, since the labour market for the higher types of education has a more nationwide character. See for some evidence Clark and Whiteman (1983) and Torrington and Hall (1991). 
market mismatches. Since training programmes usually aim to improve the short-term labour market perspectives of the unemployed, it is straightforward to base training policies on short-term forecasts, i.e. forecasts for the next year.

The second notion is that focussing on (expected) flows on the labour market has some important advantages over focusing on (expected) stocks. Therefore, on the demand side the concept of job openings is introduced, which refers to the number of jobs that are expected to become available on the labour market due to expansion demand (employment growth) and replacement demand. ${ }^{6}$

The third notion is that a comparison between the expected number of job openings and the supply of job-seekers indicates the relative scarcity of labour in a particular labour market segment. There is a shortage if the number of expected job openings exceeds the number of job-seekers, whereas there is excess supply if the opposite holds. However, according to employers, not all job-seekers are adequately qualified for a job that fits their formal educational background. In other words, an individual's educational background is not the only determinant of his suitability for a particular job. That is why discrepancy analyses often distinguish between suited job-seekers who are adequately skilled and job-seekers which are currently less suited due to, for example, personal circumstances or skill obsolescence (Hartog, 1980). Obviously, the second group of job-seekers is less competitive on the labour market than the first is.

Employers are primarily interested in suited job-seekers. For this reason the indicator for future recruitment problems $I F R P_{i}$ in a certain labour market segment $i$ confronts labour demand and suited labour supply in the following manner. ${ }^{7}$

$$
I F R P_{i}=\frac{E_{i}+J O_{i}}{E_{i}+U_{S, i}},
$$

where $E_{i}$ denotes current employment in labour segment $i$, while $J O_{i}$ and $U_{S, i}$ are the number of job openings and the number of suited job-seekers respectively. As noted before, the number of expected job openings is assumed to be the sum of expansion demand $E D_{i}$ and replacement demand $R D_{i}$ :

6. For forecasting purposes, the concept of job openings is preferred over the concept of vacancies for three reasons. First, most definitions of vacancies seem to rule out anticipating employers' recruitment policies (Russo, 1996). Furthermore, vacancies are hard to measure, since there is no unambiguous definition available and because vacancies are hard to observe and badly registered (Muysken, 1994). Abraham (1983) stresses downward bias in reported vacancy rate data. Finally, De Grip et al. (1994) argue that job-to-job mobility (which determines the difference between job openings and vacancies) is not relevant for determining the job openings for newcomers on the labour market as they lead to vacancy chains which are nothing more than a reallocation of the current workforce (Gorter and Schettkat, 1994).

7. Employment is included in the equation for scaling purposes only. 


$$
J O_{i}=E D_{i}+R D_{i}
$$

The number of suited job-seekers is assumed to consist of two groups: The unemployed jobseekers who, at the moment, are considered to be suited, $U_{1, i}$, as well as the expected number of school-leavers during the coming year, $S L_{i}$ :

$U_{S, i}=U_{1, i}+S L_{i}$

If a shortage of suited job-seekers on labour market segment $i$ is expected, then within our framework employers will have to recruit workers who are considered to be less suited at the moment. The suitability of these workers can be increased by means of additional training. The indicator for the type of mismatch $\left(I T M_{i}\right)$ shows to what degree less suited job-seekers are available to fulfill the "remaining" job openings. $I T M_{i}$ is defined as the ratio between the number of expected job openings which can not be fulfilled by the suited job-seekers, $\mathrm{JO}_{i}$ $U_{s, i}$ and the number of less suited job-seekers $U_{2, i}$ in labour market segment $i$ :

$$
I T M_{i}=\frac{\max \left(J O_{i}-U_{S, i}, 0\right)}{U_{2, i}}
$$

If $I F R P_{i}$ is larger than 1 , the numerator consists of the difference between the number of expected job openings and the number of suited job-seekers in segment $i . I T M_{i}$ indicates the number of "remaining" job openings in segment $i$ per less suited job-seeker in that segment. If $I F R P_{i}$ is smaller than 1 , there are no job openings for the less suited. That is, the numerator in equation (4) is equal to zero and therefore $I T M_{i}$ will also be equal to zero. This implies that, since there is sufficient supply of suited job-seekers, the probability that employers will recruit a less suited job seeker to fulfill their vacancies is expected to be zero.

The two indicators described in expressions (1) and (4) are helpful in characterising the specific type of demand-supply mismatch in various labour market segments. We distinguish three different situations:

1. Excess supply implies that the number of suited job-seekers exceeds the number of expected job openings, i.e $I F R P_{i}$ is smaller than 1. This means that there is no opportunity for less suited job-seekers to find a job in their own segment. Still retraining might improve their labour market perspectives;

2. A qualitative supply shortage. This type of matching problem is characterised by a shortage of suited job-seekers, i.e. IFRP is larger than 1. However, there are sufficient less suited job-seekers available with the relevant educational background. Thus $I T M_{i}$ is smaller than 1 . Since the less suited job-seekers do not fully meet the requirements imposed by the employer, additional training might prove to be an effective instrument to 
reduce the matching problems in the segment concerned and to improve the labour market perspectives of the unemployed currently considered to be less suited;

3. A quantitative supply shortage. This type of matching problem is characterised by a shortage of both suited and less suited job-seekers, i.e. both $I F R P_{i}$ and $I T M_{i}$ are larger than 1. As before, additional training might prove to be an effective instrument to improve the labour market perspectives of the less suited job-seekers. However, these additional training programmes only partly reduce the matching problems in the labour market segment concerned. Retraining programmes ought to be directed at unemployed workers in other (preferably excess supply) labour market segments to increase the supply of workers with the adequate skills.

\section{Opportunities for training}

From the above analysis, it is not always unambiguously clear which type of training is most effective in reducing matching problems. Thus, if a situation of qualitative supply shortage were to be expected, two competing instruments would be available: (1) additional training for less suited job-seekers in the labour market segment concerned or (2) retraining of jobseekers from other segments that are characterised by excess supply. We will assume that only suited job-seekers in labour market segments characterised by excess supply can participate in retraining programmes for other labour market segments. Two basic notions underlie this assumption: Firstly, retraining job-seekers in labour market segments for which a shortage of suited supply is expected is not effective. Secondly, retraining less suited jobseekers for another labour market is considered to be too costly and time-consuming.

The additional training perspectives for the less suited job-seekers are determined by a number of factors. Firstly, the own-segment IFRP clearly matters (this effect is captured in the numerator of equation (5) below). Thus, in a situation of excess supply, strictly speaking there are no opportunities to improve the labour market perspectives of less suited jobseekers by means of additional training. For this reason we shall only consider additional training perspectives whenever $I F R P_{i}$ is larger than 1 . Secondly, the additional training perspectives are determined by the total number of less suited job-seekers in the labour market segment concerned (the first term in the denominator). The higher the number of less suited job-seekers, the more candidates for an additional training programme there are and the worse the perspectives of the individual worker are. Thirdly, the additional training perspectives are related to the number of retrainable job-seekers that are in excess supply in other labour market segments (the third term in the denominator). However, it is not only the availability of candidates for retraining that matters here. A job-seeker is an attractive candidate only if there is considerable similarity between his educational background and the required skills in the labour market segment concerned. For this reason a similarity index is used to indicate the degree of competition between job-seekers (cf. section 3).

The additional training perspectives $A T P_{i}$ indicate the opportunities for less suited jobseekers in segment $i$ to improve their labour market perspectives by means of additional training and is defined as follows: 


$$
A T P_{i}=\frac{J O_{i}-U_{S, i}}{U_{2, i}+\sum_{j=m+1}^{n} S_{i j}\left(U_{S, j}-J O_{j}\right)}
$$

where $J O_{i}, U_{S, i}$ and $U_{2, i}$ are defined as before. $S_{i j}$ is an index representing the similarity between labour market segments $i$ and $j$. Basically, $S_{i j}$ measures to what extent two types of education $i$ and $j$ focus on the same occupational field. By definition, this similarity index has a value between zero (no similarity) and one (equivalence). As expression (5) shows, the set of all labour market segments is divided into two mutually exclusive subsets: Segments 1 to $m$ are expected to be characterised by a shortage of suited supply $\left(I F R P_{i}>1\right)$. On the other hand, segments $m+1$ to $n$ are expected to be characterised by excess supply $\left(I F R P_{i}<1\right)$. Since we only consider the additional training perspectives if the numerator is larger than 1 , $A T P_{i}$ is always strictly positive. It follows from (5) that the perspectives improve as $A T P_{i}$ increases.

The factors determining the additional training perspectives for the less suited job-seekers in labour market segment $i$ are also related to the retraining perspectives for suited job-seekers from a related labour market segment which is expected to be characterised by excess supply. Firstly, the retraining perspectives improve as the number of job openings in labour market segments in which there is a shortage of suited supply, increases. Furthermore, the retraining perspectives for job-seekers are determined by the total number of job-seekers who might be a candidate for a retraining programme. Finally, the perspectives are related to the number of less suited job-seekers within the various labour market segments on which the retraining programmes focus. All these factors are weighted by the similarity index between the two labour market segments. The retraining perspectives $R T P_{i}$ for job-seekers in labour segment $i$ are defined as follows:

$$
R T P_{i}=\frac{\sum_{j=1}^{m} S_{i j}\left(\frac{J O_{j}-U_{S, j}}{U_{2, j}}\right)}{\sum_{j=m+1}^{n} S_{i j}\left(U_{S, j}-J O_{j}\right)}
$$

The numerator in expression (6) is simply the indicator for the type of mismatch $\left(I T M_{j}\right)$. This means that the more the shortage of suited supply on related labour market segments has a quantitative character, the better the retraining perspectives get. In the denominator all jobseekers who are candidates for retraining are taken into account. Since both the numerator and the denominator are positive, $R T P_{i}$ is always positive. 


\section{The data: sources and methods ${ }^{8}$}

In the following we apply the framework described in section 2 to the labour market in the Dutch province of Limburg. In this section the data used will be described. Clearly, the analysis requires three types of data: the number of unemployed job-seekers by labour market segment (in our case educational types) and by degree of suitability; a one-yearahead forecast of the number of expected job openings and of the number of school-leavers by educational type.

\section{Unemployed}

Data on unemployed job-seekers are obtained from the registration system of the regional Public Employment Services (RBA). In this system (the "PGI-system") a number of personal characteristics of the unemployed is registered. ${ }^{9}$ The educational background is known for (almost) all job-seekers. Furthermore, a typology is used to indicate the degree of suitability. Four categories ("fasen") are distinguished. Job-seekers of the first category are considered to be suited for jobs which are in line with their educational background. Job-seekers of the second and the third category are considered to be less suited. This implies that they need some additional training to become suitable labour supply. Job-seekers of the fourth category are considered to be currently unsuited for a position on the labour market. In this paper, two types of job-seekers are distinguished: the suited job-seekers of the first category $\left(U_{1, i}\right)$ and the less suited job-seekers $\left(U_{2, i}\right)$ of the second and third category.

\section{Job openings}

An approach based on flow volumes has been chosen for forecasting the scarcity of various types of education on the labour market in the coming year. With this approach, forecasts are made of the flows entering and leaving the labour market. It has the advantage of showing the processes that are important for the development of labour demand and supply. Moreover, as mentioned before, this approach enables us to avoid the use of vacancy figures. ${ }^{10}$

8. Ideally our analysis would involve the specification of individual utility functions and firms' profit functions. We would then derive training as resulting from optimising behaviour, using e.g. arbitrage conditions involving two career paths (one with and the other without training). Such a framework would require the availability of (reservation) wage data though. Alternatively, one could take a social planner's perspective by specifying a social welfare function that maximises the number of unemployed finding a job at the lowest possible training costs. Data on training costs are not available either. Moreover, the social planner's optimum would eventually be no more than a first-best benchmark case for decentralised optimal decision-making.

9. The employed job-seekers, who are registered as well, are not taken into account. If they find another job and fill a job opening, a new job opening occurs. As mentioned before, in that case there is no net effect on the ratio between job openings and labour supply.

10. For a more extensive overview of regional labour market forecasting models, see Van der Laan (1996). 
The first flow volume which is important for the demand side of the labour market is expansion demand, which reflects the movement in employment levels for a particular type of education. The forecasts of regional expansion demand are based on the regional employment level forecasts by economic sector of the eleborate REGAMBEV model (Natzijl and Westra, 1993; see also Van der Laan, 1996). REGAMBEV is essentially a multiregional top-down model in which regional growth differences are caused by differences in explanatory variables. It is beyond the scope of this paper to consider this model in detail. By taking into account the expected shifts in the occupational structure of sectoral employment, the expansion demand by occupation can be determined. Since in practice the regionspecific components in the shifts in the occupational structure of employment are small, we have chosen to base these shifts on national developments (cf. De Grip and Heijke, 1998). Finally the implications of the predicted growth in the various occupational groups for the expansion demand by type of education are determined. At this point an allowance is made for any shifts which may be occurring in the educational requirements in the various occupational groups. This forecast is also based on the predicted national developments in the required skills within the various occupations.

As mentioned before, demand for newcomers on the labour market not only refers to expansion demand, but also to replacement demand, which arises when workers retire, leave the labour force under early retirement schemes or due to work disability, withdraw from the labour market temporarily, etc. However replacement demand only arises if the departure of a worker actually leads to a new job opening for a non-employed worker. If the outflow of a worker is taken as an opportunity to cut employment levels, no replacement demand results (cf. Willems and De Grip, 1993). Since detailed figures on the flows from and to the labour market are insufficiently available, cohort-change rates are used to determine the outflow by gender and by age group. In line with the expansion demand forecast method, no region-specific mobility figures are used. National institutions determine the cohortspecific outflow rates and national outflow rates are projected on the region-specific gender and age structure of the working population.

\section{School-leavers}

As indicated by equation (3) the supply of suited job-seekers is partly determinded by the number of school-leavers entering the labour market. The forecasts of the flows of schoolleavers from initial education entering the labour market that are used here, are constructed by the Dutch Ministry of Education, Culture and Science by means of a students-flow model indicating the anual flows of students within the educational system. ${ }^{11}$

11. In De Grip and Heijke (1998) a description is given of the forecasting model. 
The similarity-index plays an important role in equations (5) and (6) above. It is defined as follows:

$$
S_{i j}=\frac{\sum_{b}\left(\frac{E_{i b}}{E_{b}}\right)\left(\frac{E_{j b}}{E_{b}}\right)}{\sqrt{\sum_{b}\left(\frac{E_{i b}}{E_{b}}\right)^{2} \sum_{b}\left(\frac{E_{j b}}{E_{b}}\right)^{2}}},
$$

where $E_{i b}$ is the total number of workers with education $i$ working in occupation $b$ and $E_{b}$ is the total amount of employees working in occupation $b$. The index is calculated from Labour Force Survey data of Statistics Netherlands (CBS).

\section{Matching problems and training perspectives: A brief illustration}

We now describe expected matching problems on the labour market in Limburg in 2000. Since the labour market for higher skilled workers is to a large extent a national market, we will focus on the labour market segments at the intermediate level, for which the most complete information is available. ${ }^{13}$

Table 1 shows the expected recruitment problems for different educational types at the intermediate level. As before a first distinction is between excess supply and a supply shortage. In the table the first group of educations is characterised by excess supply, which means that the number of job openings falls short of the number of suited job-seekers in these labour market segments. It can be seen that several technical, economicadministrative as well as service educations will face surpluses of suited job-seekers. A situation of excess supply also implies that the labour market perspectives for individuals with that particular education will be rather bleak. Thus these perspectives will be worst for IVE Mechanical Engineering and IVE Social and cultural.

If $I F R P_{i}$ is larger than 1 , the indicator for the type of mismatch $I T M_{i}$ provides insight into what kind of matching problems are expected for different labour market segments. Thus, in table 1 it is also shown for which educational types the shortage of suited supply is either qualitative or quantitative in character. There is a qualitative supply shortage for IVE

12. The similarity index that we use is not without danger, since the number of individuals with a certain educational background that work in an occupation is not independent of the tension in that particular labour market segment. However, in our view the approximation that we use is the best available. The similarity index as defined here was first presented in Borghans (1992).

13. Information on lower levels of education is given in the appendix. 
Transport and harbour, which means that there are enough less suited unemployed workers available to fulfill the remaining job openings. Additional training for these workers would be sufficient to solve the recruitment problems in this labour market segment. From a supply perspective, the additional training perspectives for individuals with this education are rather limited, a view which is corroborated by the low value for the ATP (see appendix).

A wider range of educations is characterised by a quantitative supply shortage. For these educations there is a shortage of currently less suited job-seekers, i.e. ITM $M_{i}$ is larger than one. This means that additional training for these job-seekers will not be sufficient to solve the expected recruitment problems. Retraining of unemployed job-seekers on other labour market segments is required to further reduce shortages. It is evident that not all job-seekers in other educational groups can be retrained in order to fulfill the remaining job openings in an education that faces a quantitative shortage of labour supply. Obviously, retraining will be most efficient if it focuses on job-seekers whose skills are to some extent related to the type of education concerned.

Table 1

Expected recruitment problems for educational types at the intermediate level in 2000

Educational type

IFRP

ITM

No recruitment problems: excess supply

IVE Mechanical engineering $\quad 0.96$

IVE Social and cultural $\quad 0.96$

IVE Administration $\quad 0.97$

Higher General Secondary Education $\quad 0.97$

IVE Commerce $\quad 0.99$

IVE Utilities installation $\quad 0.99$

Recruitment problems: Qualitative supply shortage

IVE Transport and harbour $\quad 1.01$

0.98

Recruitment problems: Quantitative supply shortage

IVE Nursing

$1.03 \quad 1.01$

IVE Agriculture and the natural environment $\quad 1.02 \quad 1.02$

IVE Process technologies $\quad 1.02 \quad 1.02$

IVE Construction technology $\quad 1.02 \quad 1.01$

IVE Electrical technology $\quad 1.02 \quad 1.01$

IVE Automobile technology $\quad 1.01 \quad 1.01$

IVE Police, fire and defense $\quad 1.01 \quad 1.01$

\section{Source: ROA/CBS}

As noted before, there is both a demand and a supply side to expected recruitment problems. In a situation of excess supply clearly from a demand side perspective there are no or hardly any recruitment problems to be expected. At the same time the opportunities for unemployed workers in that labour market segment to find a job are rather bleak. In the case 
of supply shortages clearly the opposite holds. The indicators ATP and RTP may be given the same kind of interpretation: on the one hand these indicate in what way labour market imbalances might be reduced, on the other how the labour market opportunities of unemployed individuals might be improved.

As a matter of illustration, from the appendix it is clear that the additional training perspectives are best for IVE Nursing. Surely this may be rationalised by noting that supply shortages are largest in that particular labour market segment. This means that unemployed individuals with an educational background in IVE Nursing have a good chance of finding a job upon training themselves. At the same time, if such training were to be successfully completed, this offers an opportunity for employers to reduce recruitment problems. Nonetheless, retraining directed at unemployed workers in other labour market segments would be necessary to completely solve the problem. Unemployed workers in labour market segments that are characterised by excess supply would be the most obvious candidates. This is exactly why some types of education that are in excess supply are among those with the best retraining perspectives, such as IVE Administration and IVE Mechanical engineering.

\section{Conclusions}

In this paper we developed a framework for signalling the regional training policies required for a balanced labour market. We identified three different kinds of mismatch, i.e. excess supply, qualitative and quantitative supply shortages. It was shown that by means of additional training and retraining the recruitment problems of employers can be reduced. At the same time these programmes improve the labour market perspectives of the participating job-seekers. Since training programmes take time, the analysis should be based on (short term) forecasts of expected matching problems. Moreover, the suitability of the job-seekers should be taken into account. Finally, insight into the degree of similarity in the occupational field of the various types of education is required.

\section{References}

Abraham, K.G. (1983), "Structural-Frictional vs. Deficient Demand Unemployment: Some New Evidence", American Economic Review 73, pp. 708-724.

Borghans, L. (1992), "A Histo-Topographic Map of Dutch University Studies", ROA-W-1992/5E, Maastricht.

Clark, G.L. and J. Whiteman (1983), "Why Poor People Do not Move: Job Search Behaviour and Disequilibrium Amongst Local Labor Markets", Environment and Planning A 18, pp. 85-104.

Dijk, J. van and A. de Grip (1998), Institutions and regional labour markets in The Netherlands, pp. 105-138.

Freeman, R.B. (1975), "Legal Cobwebs: a Recursive Model of the Market for New Lawyers”, Review of Economics and Statistics 57, pp. 171-179. 
Gorter, C. and R. Schettkat (1994), "Crowding Out or Pulling In?", Discussion Paper T194-158, Tinbergen Institute, Amsterdam/Rotterdam.

Grip, A. de (1987), "Causes of Labour Supply and Demand Mismatches in the Dutch Building Trades", De Economist 135 (2), pp. 182-200.

Grip, A. de, P. Meijboom and E. Willems (1994), "Vacancies, Employment Growth and the Demand for Newcomers on the Labour Market", in: J. Muysken (ed.), Measurement and Analysis of Job Vacancies, Avebury, Aldershot, pp. 101-125.

Grip, A. de and H. Heijke (1998), "Beyond Manpower Planning: ROA's Labour Market Model and Its Forecasts to 2002", ROA-W-1998/6E, Maastricht.

Hartog, J. (1980), Tussen vraag en aanbod, Stenfert Kroese, Leiden.

Hoof, J.J. van and J. Dronkers (1980), Onderwijs en Arbeidsmarkt, Van Loghum Slaterus, Deventer. ILO (1995), World Employment 1995, International Labour Office, Geneva.

Laan, L. van der (1996), "A Review of Regional Labour Supply and Demand Forecasting in the European Union", Environment and Planning A 28, pp. 2105-2123.

Laan, L. van der and S. Ruesga (1998), "Introduction", in: Van der Laan, L. and S. Ruesga (ed.), Institutions and Regional Labour Markts in Europe, Ashgate, Aldershot.

Machin S., A. Ryan and J. van Reenen (1998), "Technology and Changes in Skill Structure: Evidence From an International Pavel of Industries", CEP Discussion Paper No. 297, London.

Muysken, J., "Introduction", in: J. Muysken (ed.) (1994), Measurement and Analysis of Job Vacancies, Avebury, Aldershot, pp. 1-11.

Natzijl, H. en P. Westra (1993), "RAMONA, een Regionaal Arbeidsmarkt-model voor de Arbeidsvoorziening", OAV werkdocument 93-10, Centraal Bestuur voor de Arbeidsvoorziening, Rijswijk.

ROA (1999), De Limburgse Arbeidsmarkt 1999-2004, ROA-R-1999/3, Researchcentrum voor Onderwijs en Arbeidsmarkt, Maastricht.

ROA (1999), De Arbeidsmarkt naar Opleiding en Beroep tot 2004, ROA-R-1999/8, Researchcentrum voor Onderwijs en Arbeidsmarkt, Maastricht.

Russo, G. (1996), Firms' Recruitment Behaviour; an Empirical Investigation of the Use of Search Channels, the Rate of Arrival of Applicants, and the Spatial Radius of Search, Thesis, Thesis Publishers, Amsterdam.

Schmid, G., J. O'Reilly and K. Schömann (1996), International Handbook of Labour Market Policy and Evaluation, Edward Elgar, Cheltenham/Brookfield.

Torrington, D. and L. Hall (1991), Personell Management, Prentince Hall.

Willems, E. and A. de Grip (1993), "Forecasting Replacement Demand by Occupation and Education", International Journal of Forecasting 9 (3), pp. 220-229.

Zarkin, G.A. (1983), "Occupational Choice: An Application to the Market for Public School Teachers", Quaterly Journal of Economics 100, pp. 409-446. 
Appendix: Labour market indicators for different types of education

\begin{tabular}{|c|c|c|c|c|}
\hline & IFRP & ITM & ATP & RTP \\
\hline Primary Education & 0.98 & 0.93 & & 0.02 \\
\hline Lower General Secondary Education & 0.96 & 0.92 & & 0.04 \\
\hline PVE Agriculture & 0.95 & 0.95 & & 0.01 \\
\hline PVE Construction trades & 0.91 & 0.84 & & 0.01 \\
\hline PVE Mechanical trades & 1.01 & 1.00 & 0.03 & 0.02 \\
\hline PVE Automobile trades & 1.00 & 1.00 & 0.00 & 0.02 \\
\hline PVE Electrical trades & 0.98 & 1.00 & & 0.01 \\
\hline PVE Administration and commerce & 0.90 & 0.84 & & 0.02 \\
\hline PVE Community, care, hotel and catering & 0.98 & 0.88 & & 0.01 \\
\hline Higher General Secondary Education & 0.97 & 0.96 & & 0.09 \\
\hline IVE Agriculture and the natural environment & 1.02 & 1.02 & 0.18 & 0.03 \\
\hline IVE Construction technology & 1.02 & 1.01 & 0.10 & 0.05 \\
\hline IVE Utilities installation & 0.99 & 0.99 & & 0.05 \\
\hline IVE Mechanical engineering & 0.96 & 0.93 & & 0.10 \\
\hline IVE Automobile technology & 1.01 & 1.01 & 0.07 & 0.03 \\
\hline IVE Electrical technology & 1.02 & 1.01 & 0.18 & 0.09 \\
\hline IVE Process technologies & 1.02 & 1.02 & 0.18 & 0.03 \\
\hline IVE Transport and harbour & 1.01 & 0.98 & 0.04 & 0.04 \\
\hline IVE Nursing & 1.03 & 1.01 & 0.60 & 0.17 \\
\hline IVE Social and cultural & 0.96 & 0.94 & & 0.08 \\
\hline IVE Community care & 1.00 & 1.00 & 0.06 & 0.04 \\
\hline IVE Administation & 0.97 & 0.98 & & 0.11 \\
\hline IVE Commerce & 0.99 & 0.98 & & 0.05 \\
\hline IVE Secretarial & 1.01 & 1.00 & 0.04 & 0.03 \\
\hline IVE Police, fire and defense & 1.01 & 1.01 & 0.16 & 0.04 \\
\hline
\end{tabular}

Source: ROA/CBS 
